\title{
Phylogenetic relationships of selected genera of Lutjanidae inferred from mitochondrial regions, with a note on the taxonomic status of Pinjalo pinjalo
}

\section{Relaciones filogenéticas de algunos géneros de la familia Lutjanidae inferidas a partir de regiones mitocondriales, con una nota sobre la taxonomía de Pinjalo pinjalo}

\author{
Cecilia Chuํㅜ, Mohammed Rizman-Idid ${ }^{1,2 *}$, Chong Ving Ching ${ }^{1,2}$ \\ ${ }^{1}$ Institute of Biological Sciences, Faculty of Science, University of Malaya, 50603 Lembah Pantai, \\ Kuala Lumpur, Malaysia. \\ ${ }^{2}$ Institute of Ocean and Earth Sciences, University of Malaya, 50603 Lembah Pantai, Kuala Lumpur, Malaysia. \\ * Corresponding author. Email: rizman@um.edu.my
}

\begin{abstract}
Phylogenetic relationships of 43 species in 11 genera, representing four subfamilies of the family Lutjanidae and two genera of the family Caesionidae, were inferred using mitochondrial DNA (mtDNA) cytochrome c oxidase subunit I (COI). Further assessment using the mtDNA control region (CR) was carried out to infer the relationship between the Indian and western Pacific types of Lutjanus russellii collected from the coast of Peninsular Malaysia. A total of 11 and 12 species were sequenced for COI and CR genes, respectively. Clade formation reflects, to some extent, the species groupings based on morphological characteristics and their biogeography. The close phylogenetic relationship between Pinjalo pinjalo and the Lutjanus red snappers (Lutjanus malabaricus and Lutjanus sebae) warrants a taxonomic revision of the former as the two genera are currently separated based on non-exclusive morphological characters. A sequence divergence of $4.2 \%$ between the Indian and western Pacific types of $L$. russellii as well as the morphological and biogeographical differences may suggest two separate species.
\end{abstract}

Key words: Lutjanus, Pinjalo, COI, barcoding, taxonomic revision.

RESUMEN. Las relaciones filogenéticas de 43 especies pertenecientes a 11 géneros, representando cuatro subfamilias de la familia Lutjanidae y dos géneros de la familia Caesionidae, fueron inferidas a partir del gen mitocondrial citocromo c oxidasa subunidad I (COI). Además, se usó la región control (RC) del ADN mitocondrial para inferir la filogenia entre los tipos de Lutjanus russellii del océano Índico y el Pacífico occidental recolectados en las costas de la península de Malasia. Se generaron secuencias de COI (11 especies) y RC (12 especies). Los clados generados concuerdan con las agrupaciones propuestas anteriormente basadas en la morfología y biogeografía de las especies. La relación filogenética cercana entre Pinjalo pinjalo y los pargos rojos Lutjanus malabaricus y Lutjanus sebae justifica la revisión taxonómica de los mismos ya que los caracteres morfológicos empleados para diferenciar ambos géneros son ambiguos. La divergencia de las secuencias (4.2\%) entre los dos tipos de L. russellii (Índico y Pacifico occidental), así como la caracterización morfológica y la información biogeográfica permiten sugerir que son dos especies distintas.

Palabras clave: Lutjanus, Pinjalo, COI, código de barras genético, revisión taxonómica.

\section{INTRODUCTION}

About 112 species of snappers (family Lutjanidae) are reported to exist in the warm seas of the Indian Ocean and the tropical and subtropical parts of the western Pacific Ocean (Masuda 1984). The largest species diversity occurs in the genus Lutjanus, with 64 out of a total of 72 species found in the subfamily Lutjaninae (Anderson and Allen 2001). Lutjaninae is composed of the genera Lutjanus, Pinjalo, Macolor, Ocyurus, and Rhomboplites, the last two being monotypic genera found only in western Atlantic waters (Allen 1985). Malaysian snappers are represented by 38 species in 10 genera, which include Lutjanus, Pinjalo, and Macolor (Chong et al. 2010).

\section{INTRODUCCIÓN}

Alrededor de 112 especies de pargos (familia Lutjanidae) habitan en las aguas templadas del océano Índico y en las partes tropicales y subtropicales del océano Pacífico occidental (Masuda 1984). El género Lutjanus presenta la mayor diversidad de especies, con 64 del total de 72 especies de la subfamilia Lutjaninae (Anderson y Allen 2001). Esta subfamilia está compuesta por los géneros Lutjanus, Pinjalo, Macolor, Ocyurus y Rhomboplites, los últimos dos siendo géneros monotípicos que sólo se encuentran en aguas del Atlántico occidental (Allen 1985). Los pargos de Malasia están representados por 38 especies pertenecientes a 10 géneros, entre ellos Lutjanus, Pinjalo y Macolor (Chong et al. 2010). 
Previously, Johnson (1980) suggested monophyly of Lutjanus species based on their primitive and derivative morphological characters, but recent DNA sequence based phylogenies have rendered the genus Lutjanus as paraphyletic due to the phylogenetic associations of some Lutjanus species with other genera of the families Lutjanidae and Caesionidae (Chow and Walsh 1992, Miller and Cribb 2007, Gold et al. 2011).

In the present study, we hypothesize that the genus Pinjalo is related to Lutjanus, specifically Pinjalo pinjalo to Lutjanus malabaricus and Lutjanus sebae. Morphologically, the red Pinjalo snapper resembles the two Lutjanus red snappers and has been often misidentified as the latter (Zhang et al. 2006). Phylogenetic affinities between the Indian Ocean (with body stripes) and the western Pacific (without body stripes) types of Lutjanus russellii were also investigated as the two types have never been stated in previous phylogenetic studies.

The mitochondrial DNA cytochrome c oxidase subunit I (COI) was used to barcode and infer phylogenetic relationships of Lutjanidae, since many sequences are available for comparison from previous studies (Ward and Holmes 2007, Steinke et al. 2009, Victor et al. 2009, Asgharian et al. 2011, Gold et al. 2011, Lakra et al. 2011, Zhang and Hanner 2011). The relationship between the two conspecifics of $L$. russellii was further investigated using the mitochondrial DNA control region (CR) sequence since it better resolves relationships among populations, subspecies, or recently diverged species (Parker et al. 1998, Shaw et al. 2000).

\section{MATERIALS AND METHODS}

\section{Sampling}

A total of 441 snapper specimens were collected between August 2009 and December 2010 from the coastal waters of Peninsular Malaysia and neighboring islands using trawl nets, hook and lines, and traps. Fish from known locations were also purchased from commercial and artisanal landing sites. Muscle tissues or fin clips of each collected specimen were preserved immediately in 95\% ethanol in the field, before keeping whole specimens in $10 \%$ formalin, which were subsequently measured, photographed, and identified following the identification keys of Anderson and Allen (2001). Two to five specimens of each of the 10 Lutjanus species (L. argentimaculatus, L. carponotatus, $L$. fulviflamma, $L$. johnii, L. lutjanus, L. madras, L. malabaricus, L. quinquelineatus, L. sebae, and L. vitta) and one Pinjalo species (P. pinjalo) were used for the phylogenetic study. For L. russellii, a total of 15 specimens (12 Indian and 3 western Pacific) were used for the phylogenetic study.

\section{DNA extraction}

Ethanol-preserved tissue samples were digested using $10 \mathrm{mg} \mathrm{L}^{-1}$ proteinase $\mathrm{K}$, in $300 \mu \mathrm{L}$ extraction buffer with $2 \%$
Johnson (1980) propuso la monofilia de las especies del género Lutjanus con base en sus caracteres morfológicos primitivos y derivados, pero las recientes filogenias basadas en las secuencias de ADN han sugerido que este género es parafilético debido a las asociaciones filogenéticas de algunas especies de Lutjanus con otros géneros de las familias Lutjanidae y Caesionidae (Chow y Walsh 1992, Miller y Cribb 2007, Gold et al. 2011).

En el presente trabajo planteamos la hipótesis de que el género Pinjalo está relacionado con el género Lutjanus, específicamente la especie Pinjalo pinjalo con las especies Lutjanus malabaricus y Lutjanus sebae. Estas tres especies se parecen morfológicamente y $P$. pinjalo con frecuencia ha sido erróneamente identificada (Zhang et al. 2006). También se estudiaron las afinidades filogenéticas entre Lutjanus russellii del océano Índico (con rayas corporales) y del Pacífico occidental (sin rayas corporales) ya que aparentemente nunca se han mencionado los dos tipos en otros trabajos filogenéticos.

Se usó el gen mitocondrial citocromo c oxidasa subunidad I (COI) para obtener el código de barra genético e inferir las relaciones filogenéticas de Lutjanidae, ya que es posible realizar comparaciones con varias secuencias obtenidas en trabajos previos (Ward y Holmes 2007, Steinke et al. 2009, Victor et al. 2009, Asgharian et al. 2011, Gold et al. 2011, Lakra et al. 2011, Zhang y Hanner 2011). Además, se examinó la relación entre los dos conespecíficos de $L$. russellii mediante la secuencia de la región control (RC) del ADN mitocondrial porque resuelve mejor las relaciones entre poblaciones, subespecies o especies recientemente divergidas (Parker et al. 1998, Shaw et al. 2000).

\section{MATERIALES Y MÉTODOS}

\section{Muestreo}

Entre agosto de 2009 y diciembre de 2010 se capturaron 441 especímenes de pargos de las aguas costeras de la península de Malasia e islas vecinas con redes de arrastre, caña y anzuelo, y trampas. También se adquirieron peces procedentes de sitios conocidos en puntos de desembarques comerciales y artesanales. En el campo, inmediatamente se preservaron muestras de tejido muscular o aleta de cada espécimen en etanol al 95\%. Los especímenes enteros fueron preservados en formalina al $10 \%$ y subsecuentemente fueron medidos, fotografiados e identificados según las claves de identificación de Anderson y Allen (2001). Para el estudio filogenético se usaron de dos a cinco especímenes de cada una de las 10 especies de Lutjanus (L. argentimaculatus, L. carponotatus, L. fulviflamma, $L$. johnii, L. lutjanus, $L$. madras, L. malabaricus, L. quinquelineatus, L. sebae y $L$. vitta) y una especie de Pinjalo (P. pinjalo). Para el estudio filogenético de $L$. russellii, se usaron 15 especímenes (12 del tipo Índico y 3 del Pacífico occidental). 
sodium dodecyl sulfate (SDS). DNA was extracted using the modified phenol-chloroform method (Taggart et al. 1992).

\section{PCR amplification and sequencing}

The partial fragment of the COI gene was amplified using the barcoding primers FishF1, FishR1, FishF2, and FishR2 (Ward et al. 2005). We prepared $50 \mu \mathrm{L}$ of polymerase chain reaction (PCR) mixtures containing $5 \mu \mathrm{L}$ of $10 \times$ PCR buffer, $5 \mathrm{mM} \mathrm{MgCl} 2,0.05 \mathrm{mM}$ dNTP mix, $0.1 \mu \mathrm{M}$ of each primer, and 1.2 U Taq polymerase (Fermentas), with 5-10 ng of each template DNA. PCR was performed using a MultiGene TC9600-G thermal cycler (Labnet International Inc.). Initial denaturation step was at $95^{\circ} \mathrm{C}$ for $2 \mathrm{~min}$, followed by 35 cycles of denaturation at $94^{\circ} \mathrm{C}$ for $0.5 \mathrm{~min}$, annealing at $54^{\circ} \mathrm{C}$ for $0.5 \mathrm{~min}$, and elongation at $72^{\circ} \mathrm{C}$ for $1 \mathrm{~min}$. The cycles ended with a final elongation step at $72{ }^{\circ} \mathrm{C}$ for $10 \mathrm{~min}$ and held at $4{ }^{\circ} \mathrm{C}$.

The left domain of CR was amplified using primers Pro889U20 and TDKD1291L21 (Salini et al. 2006). The $50 \mu \mathrm{L}$ PCR mixtures included $5 \mu \mathrm{L}$ of $10 \times$ PCR buffer, $5 \mathrm{mM} \mathrm{MgCl} 2,0.4 \mathrm{mM}$ dNTP mix, $0.8 \mu \mathrm{M}$ of each primer, and $4 \mathrm{U}$ Taq polymerase (Fermentas), with 5-10 ng of each template DNA. PCR was performed using an Eppendorf Mastercycler (Eppendorf AG, Hamburg, Germany). The initial denaturation for PCR was at $94^{\circ} \mathrm{C}$ for $1.5 \mathrm{~min}$, followed by 35 cycles of denaturation at $94^{\circ} \mathrm{C}$ for $5 \mathrm{~s}$, annealing at $50^{\circ} \mathrm{C}$ for $0.5 \mathrm{~min}$, and elongation steps at $72{ }^{\circ} \mathrm{C}$ for $0.5 \mathrm{~min}$. Final elongation was at $72{ }^{\circ} \mathrm{C}$ for $5 \mathrm{~min}$ and held at $4{ }^{\circ} \mathrm{C}$.

The PCR products were purified using the GeneJET PCR Purification Kit (Fermentas), following the manufacturer's protocol. Forward and reverse sequencing of the purified PCR products was performed using the BigDye Terminator v3.1 Cycle Sequencing Kit (Applied Biosystem).

\section{Sequence analysis}

The DNA sequences were checked and edited using Sequence Scanner (Applied Biosystems) to create a consensus sequence for each specimen and they were deposited in GenBank. With the inclusion of reference sequences from GenBank, multiple sequence alignment and analysis of nucleotide variation of COI and CR sequences was done in MEGA4.0 (Tamura et al. 2007). All DNA sequences analyzed in this study are listed in table 1 .

\section{Phylogenetic analyses}

The evolutionary model for COI sequences was chosen based on the Akaike Information Criterion (AIC) using Modeltest3.7 (Posada and Crandall 1998), whereas the corrected AIC was adopted for CR sequences in jModeltest (Posada 2008). By incorporating the respective evolutionary models, phylogenetic trees were constructed separately for both sets of sequences by Bayesian inference analysis. The

\section{Extracción de ADN}

Las muestras de tejido preservadas en etanol fueron digeridas con $10 \mathrm{mg} \mathrm{L}^{-1}$ de proteinase $\mathrm{K}$, en $300 \mu \mathrm{L}$ de tampón de extracción con dodecil sulfato sódico (SDS) al 2\%. El ADN fue extraído mediante el método modificado de fenol-cloroformo (Taggart et al. 1992).

\section{Amplificación y secuenciación de ADN}

Se amplificó un fragmento parcial del gen COI con los cebadores FishF1, FishR1, FishF2 y FishR2 (Ward et al. 2005). Para la reacción en cadena de la polimerasa (PCR por sus siglas en inglés) se usó una mezcla con un volumen final de $50 \mu \mathrm{L}$ que contenía $5 \mu \mathrm{L}$ de amortiguador para PCR 10×, $5 \mathrm{mM}$ de $\mathrm{MgCl}_{2}, 0.05 \mathrm{mM}$ de dNTPs, $0.1 \mu \mathrm{M}$ de cada uno de los cebadores y $1.2 \mathrm{U}$ de Taq polimerasa (Fermentas), con 5-10 ng de cada plantilla de ADN. La PCR se realizó en un termociclador MultiGene TC9600-G (Labnet International Inc.). Las condiciones de amplificación fueron desnaturalización inicial a $95^{\circ} \mathrm{C}$ durante 2 min, seguida por 35 ciclos de desnaturalización a $94{ }^{\circ} \mathrm{C}$ durante 0.5 min, hibridación a $54{ }^{\circ} \mathrm{C}$ durante 0.5 min, extensión a $72^{\circ} \mathrm{C}$ durante 1 min, y una extensión final a $72{ }^{\circ} \mathrm{C}$ durante 10 min y mantenida a $4{ }^{\circ} \mathrm{C}$.

El dominio izquierdo de RC se amplificó con los cebadores Pro889U20 y TDKD1291L21 (Salini et al. 2006). Para la PCR se usó una mezcla con un volumen final de $50 \mu \mathrm{L}$ que contenía $5 \mu \mathrm{L}$ de amortiguador para PCR $10 \times, 5 \mathrm{mM}$ de $\mathrm{MgCl}_{2}, 0.4 \mathrm{mM}$ de dNTPs, $0.8 \mu \mathrm{M}$ de cada cebador y $4 \mathrm{U}$ de Taq polimerasa (Fermentas), con 5-10 ng de cada plantilla de ADN. La PCR se realizó en un termociclador (Eppendorf AG, Hamburgo, Alemania). La desnaturalización inicial para la PCR fue a $94{ }^{\circ} \mathrm{C}$ durante $1.5 \mathrm{~min}$, seguida por 35 ciclos de desnaturalización a $94{ }^{\circ} \mathrm{C}$ durante $5 \mathrm{~s}$, hibridación a $50{ }^{\circ} \mathrm{C}$ durante $0.5 \mathrm{~min}$, extensión a $72{ }^{\circ} \mathrm{C}$ durante $0.5 \mathrm{~min}$, y una extensión final a $72{ }^{\circ} \mathrm{C}$ durante 5 min y mantenida a $4{ }^{\circ} \mathrm{C}$.

Los productos de PCR fueron purificados con un kit comercial (GeneJET PCR Purification Kit, Fermentas), siguiendo las instrucciones del fabricante. La secuenciación en ambos sentidos de los productos purificados se realizó con el BigDye Terminator v3.1 Cycle Sequencing Kit (Applied Biosystem).

\section{Análisis de secuencias}

Las secuencias de ADN se revisaron y editaron con el programa Sequence Scanner (Applied Biosystems) para generar una secuencia consenso para cada espécimen, y se depositaron en GenBank. Con la inclusión de las secuencias de referencia de GenBank, se realizó un alineamiento múltiple de secuencias y un análisis de la variación de nucleótidos de las secuencias de COI y RC con el programa MEGA4.0 (Tamura et al. 2007). Todas las secuencias de ADN analizadas en este estudio se muestran en la tabla 1. 
Table 1. List of species and corresponding GenBank accession numbers for the cytochrome c oxidase subunit I (COI) and control region sequences analyzed in this study.

Tabla 1. Lista de especies y números de accesión de GenBank correspondientes a las secuencias de citocromo c oxidasa subunidad I (COI) y la región control analizadas en este trabajo.

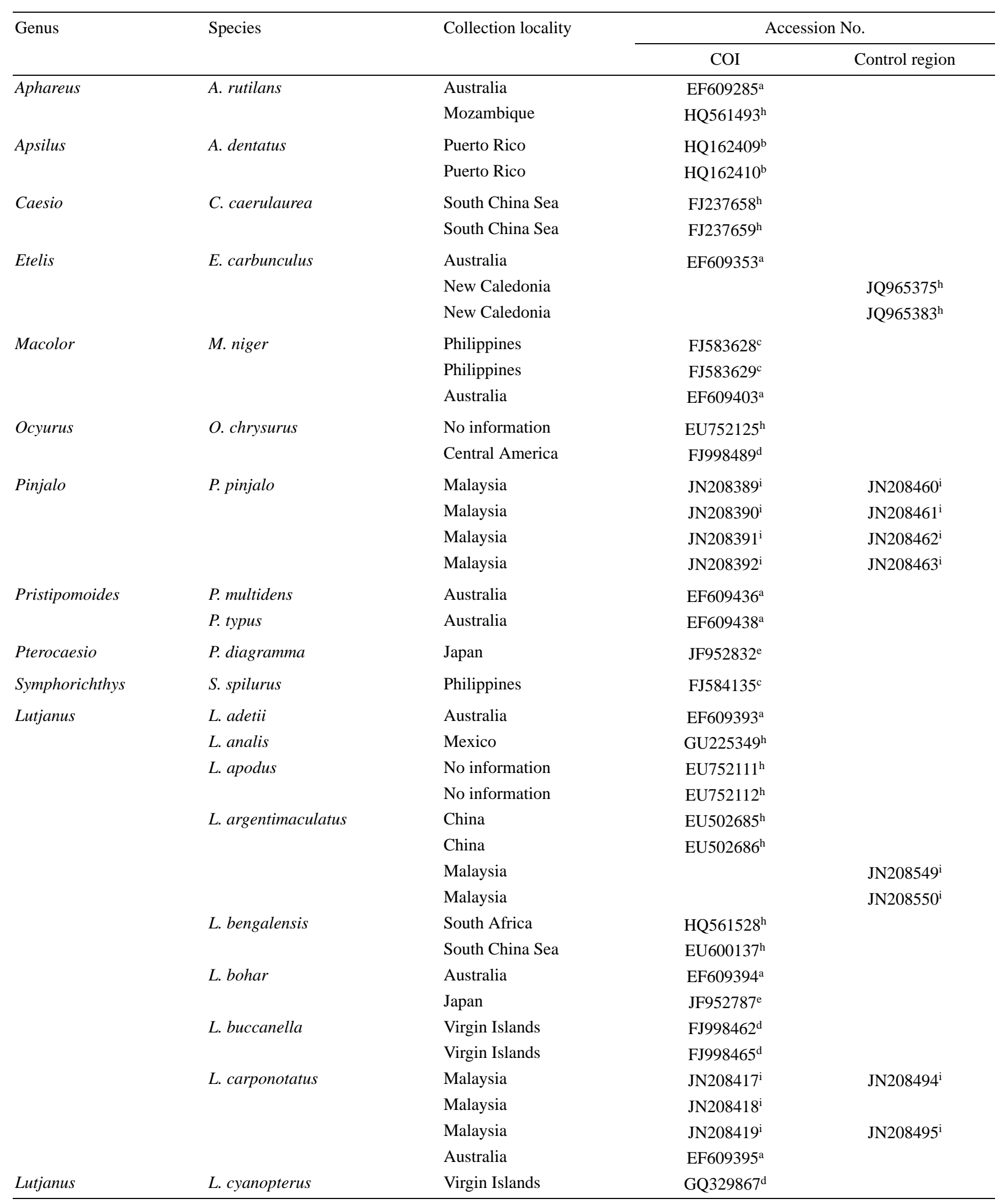


(Continued)

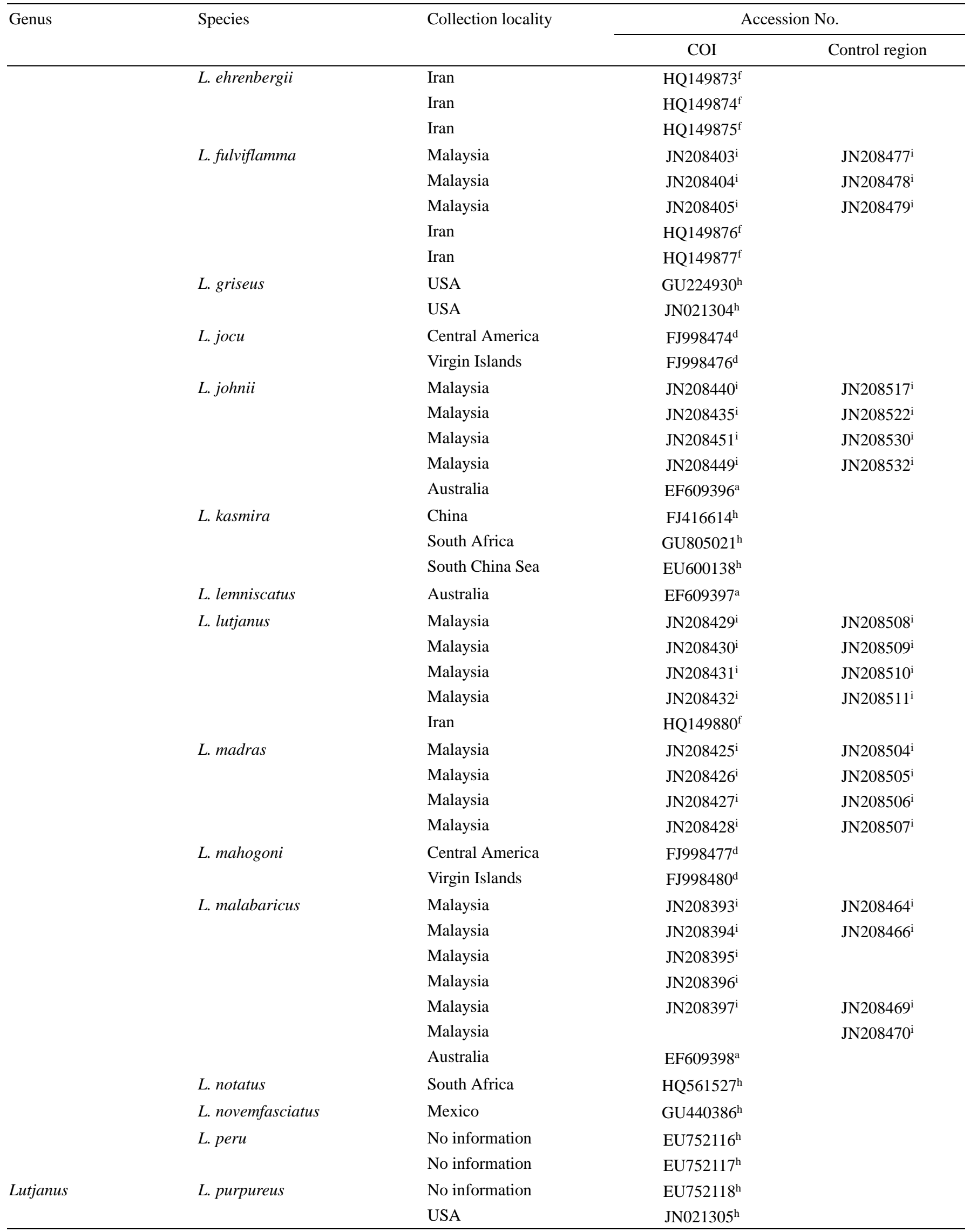


(Continued)

\begin{tabular}{|c|c|c|c|c|}
\hline \multirow[t]{2}{*}{ Genus } & \multirow[t]{2}{*}{ Species } & \multirow[t]{2}{*}{ Collection locality } & \multicolumn{2}{|c|}{ Accession No. } \\
\hline & & & COI & Control region \\
\hline & L. quinquelineatus & Malaysia & JN208400 & JN208474 ${ }^{\mathrm{i}}$ \\
\hline & & Malaysia & $\mathrm{JN} 208402^{\mathrm{i}}$ & JN208476 $6^{\mathrm{i}}$ \\
\hline & & Australia & EF609399a & \\
\hline & L. russellii (Indian Ocean) & Malaysia & JN208406 & JN208480i \\
\hline & & Malaysia & $\mathrm{JN} 208407^{\mathrm{i}}$ & JN208481 \\
\hline & & Malaysia & JN208408i & JN208482 ${ }^{\mathrm{i}}$ \\
\hline & & Malaysia & JN208409i & JN208483 ${ }^{\mathrm{i}}$ \\
\hline & & Malaysia & JN208413 & JN208487 \\
\hline & & Malaysia & & JN208488 \\
\hline & & Malaysia & & JN208489i \\
\hline & & Malaysia & & JN208490 \\
\hline & & Malaysia & & JN208491 \\
\hline & & India & EU148540" & \\
\hline & L. russellii (W Pacific) & Malaysia & JN208414 & \\
\hline & & Malaysia & JN208415 & \\
\hline & & Malaysia & JN208416 & JN208492 \\
\hline & L. synagris & USA & JN021307 & \\
\hline & & USA & JN021308 & \\
\hline & L. vitta & Malaysia & JN208420i & JN208496 \\
\hline & & Malaysia & JN208421 & \\
\hline & & Malaysia & JN208422 & \\
\hline & & Malaysia & JN208423 & JN208499i \\
\hline & & Malaysia & JN208424 & JN208500 \\
\hline & & Malaysia & & JN208501 ${ }^{\mathrm{i}}$ \\
\hline & & Australia & EF609402 $^{\mathrm{a}}$ & \\
\hline & L. vivanus & Mexico & GU225380h & \\
\hline & & Virgin Islands & FJ998485d & \\
\hline No. of sequences & & & 115 & 52 \\
\hline
\end{tabular}

${ }^{\mathrm{a}}$ Ward and Holmes (2007); ${ }^{\mathrm{b}}$ Gold et al. (2011); ${ }^{\mathrm{c}}$ Steinke et al. (2009); ${ }^{\mathrm{d}}$ Victor et al. (2009); ${ }^{\mathrm{e}}$ Zhang and Hanner (2011); ${ }^{\mathrm{f}}$ Asgharian et al. (2011); ${ }^{\mathrm{L}}$ Lakra et al. (2011); ${ }^{\mathrm{h}}$ unpulished sources; ${ }^{\mathrm{i}}$ this study. 
Bayesian analysis was implemented in MrBayes 3.1.2 (Huelsenbeck and Ronquist 2001) over 8,000,000 generations via four Markov Chain Monte Carlo chains, with tree sampling every 100 generations. Only branches with more than 0.70 posterior probabilities were considered. The COIbased phylogenetic tree was rooted with Aphareus rutilans (subfamily Etelinae) with the addition of the genera Pristipomoides and Etelis (subfamily Etelinae), Apsilus (subfamily Apsilinae), and Symphorichthys (subfamily Paradicichthyinae) to achieve better tree resolution among the Lutjaninae species. For the CR-based phylogenetic tree, Etelis carbunculus was used to root the tree.

\section{RESULTS}

\section{DNA sequence variation}

A total of $48 \mathrm{COI}$ sequences were directly obtained from this study, disregarding two specimens of L. argentimaculatus that failed to amplify for COI. The 606 bp COI sequence alignment contained 219 variable sites, of which 212 were parsimony informative. The transition/transversion ratio was 2.9. G-bias was observed at both the second and third codon positions of COI with nucleotide compositions $\mathrm{A}=24.9 \%$, $\mathrm{C}=28.8 \%, \mathrm{G}=18.4 \%$, and $\mathrm{T}=27.9 \%$.

The CR sequence alignment was 461 bp in length, which includes 14 to 76 bp sized indels. There were 276 variable and 269 parsimony informative sites with transition/transversion ratio of 0.78 . The bases were fractioned as $\mathrm{A}=35.7 \%$, $\mathrm{C}=19.6 \%, \mathrm{G}=13.8 \%$, and $\mathrm{T}=30.9 \%$.

\section{Evolutionary model}

The Modeltest result suggested the Tamura-Nei evolutionary model with invariable and gamma distribution $(\operatorname{TrN}+\mathrm{I}+\mathrm{G} ; \mathrm{I}=0.6289 ; \mathrm{G}=1.3905)$ for COI sequences, whereas for the $\mathrm{CR}$ sequences, the program jModeltest suggested the three-parameter model with invariable sites and gamma distribution (TPM3uf $+\mathrm{I}+\mathrm{G} ; \mathrm{I}=0.2940 ; \mathrm{G}=$ 1.2110). Base frequencies for COI were 0.2899, 0.3106, 0.1216 and 0.2779 for $\mathrm{A}, \mathrm{C}, \mathrm{G}$, and $\mathrm{T}$, respectively, with incorporated rate matrix for the substitution model in the Bayesian inference analysis: $[\mathrm{A}-\mathrm{C}]=1.0000$; $[\mathrm{A}-\mathrm{G}]=$ 19.1232; $[\mathrm{A}-\mathrm{T}]=1.0000 ;[\mathrm{C}-\mathrm{G}]=1.0000 ;[\mathrm{C}-\mathrm{T}]=11.1862$; $[\mathrm{G}-\mathrm{T}]=1.0000$. Unequal base frequencies were also observed in CR, with 0.3801, 0.2024, 0.1120, and 0.3056 for A, C, G, and T, respectively. The incorporated rate matrix for $\mathrm{CR}$ was $[\mathrm{A}-\mathrm{C}]=0.6564 ;[\mathrm{A}-\mathrm{G}]=3.9776$; $[\mathrm{A}-\mathrm{T}]=1.0000$; $[\mathrm{C}-\mathrm{G}]=0.6564 ;[\mathrm{C}-\mathrm{T}]=3.9776 ;[\mathrm{G}-\mathrm{T}]=1.0000$.

\section{COI-based phylogenetic tree}

The COI phylogram shows that the subfamilies Etelinae, Apsilinae, and Paradicichthyinae are basal to Lutjaninae (fig. 1). All species in Lutjaninae are monophyletic except

\section{Análisis filogenético}

El modelo de evolución para las secuencias de COI se escogió con base en el Criterio de Información de Akaike (AIC) mediante el programa Modeltest3.7 (Posada y Crandall 1998), mientras que para las secuencias de RC se usó el AIC corregido con el paquete jModeltest (Posada 2008). Al incorporar los modelos de evolución respectivos, se construyeron árboles filogenéticos por separado para ambos conjuntos de secuencias mediante un análisis de inferencia bayesiana. El análisis bayesiano se llevó a cabo en MrBayes 3.1.2 (Huelsenbeck y Ronquist 2001) con cuatro cadenas de Markov Monte Carlo por 8,000,000 generaciones, muestreando un árbol cada 100 generaciones. Sólo se consideraron las ramas con probabilidades posteriores superiores a 0.70 . El árbol filogenético basado en las secuencias de COI fue arraigado con Aphareus rutilans (subfamilia Etelinae), con la adición de los géneros Pristipomoides y Etelis (subfamilia Etelinae), Apsilus (subfamilia Apsilinae) y Symphorichthys (subfamilia Paradicichthyinae) para lograr una mejor resolución de las especies de la subfamilia Lutjaninae. El árbol filogenético basado en las secuencias de RC fue arraigado con Etelis carbunculus.

\section{RESULTADOS}

\section{Variación de las secuencias de ADN}

Se obtuvieron 48 secuencias de COI, sin considerar dos especímenes de L. argentimaculatus para los cuales no se logró la amplificación de COI. La alineación de la secuencia de 606 pb de COI presentó 219 sitios variables, de los cuales 212 fueron parsimoniosamente informativos. La razón transición/transversión fue de 2.9. Se observó sesgo hacia G en tanto la segunda como la tercera posición del codón de COI. Las proporciones de las bases fueron $\mathrm{A}=24.9 \%, \mathrm{C}=$ $28.8 \%, \mathrm{G}=18.4 \%$ y $\mathrm{T}=27.9 \%$.

La alineación de la secuencia de RC fue de $461 \mathrm{pb}$ de largo, que incluye inserciones/eliminaciones de 14 a 76 pb. Se observaron 276 sitios variables y 269 sitios parsimoniosamente informativos. La razón transición/transversión fue de 0.78. Las proporciones de las bases fueron $\mathrm{A}=35.7 \%, \mathrm{C}=$ $19.6 \%, \mathrm{G}=13.8 \%$ y $\mathrm{T}=30.9 \%$.

\section{Modelo de evolución}

Para las secuencias de COI, el programa Modeltest sugirió el modelo de evolución de Tamura-Nei con una proporción de sitios invariantes y distribución gamma $(\operatorname{TrN}+\mathrm{I}+\mathrm{G}$; $I=0.6289 ; G=1.3905)$. Para las secuencias de $R C$, el programa jModeltest sugirió el modelo de tres parámetros con una proporción de sitios invariantes y distribución gamma (TPM3uf + I + G; I = 0.2940; G = 1.2110). Las frecuencias de las bases para COI fueron 0.2899, 0.3106, 0.1216 y 0.2779 para A, C, G y T, respectivamente, con una matriz 
for L. bohar because L. bohar (EF609394) did not cluster with its conspecific L. bohar (JF952787).

The Lutjaninae species were defined into six major clades, based on a combination of well-supported branches and previous clade definitions (Miller and Cribb 2007, Victor et al. 2009, Wang et al. 2010, Gold et al. 2011). Clades A-E are supported with over 0.90 posterior probabilities, whereas clade $\mathrm{F}$ with only 0.73 . Branching order is resolved for clades A-C; however, clades D-F form a polytomy. Clade A consists of P. pinjalo, L. malabaricus, L. adetii, and L. sebae, with an average sequence divergence of $12.9 \%( \pm 1.2)$; the lowest sequence divergence is $11.8 \%$ between $L$. adetii and $L$. malabaricus, while the highest is $14.0 \%$ between P. pinjalo and L. sebae. Clade B consists of Macolor niger and two species of the family Caesionidae (Pterocaesio diagramma and Caesio caerulaurea), with an average sequence divergence of $10.9 \%( \pm 0.4)$. Clades $C$ and D comprise Lutjanus species from the western Atlantic and eastern Pacific, whereas the Lutjanus species in clades $\mathrm{E}$ and $\mathrm{F}$ are mostly from the western Pacific and Indian Ocean. Ocyurus chrysurus is found in clade C with $L$. analis, $L$. buccanella, $L$. synagris, L. mahogoni, L. vivanus, L. purpureus, and L. peru, with an average sequence divergence of $6.3 \%( \pm 0.6)$, ranging from $1.9 \%$ to $8.9 \%$. Clade D only contains L. griseus, L. jocu, and $L$. apodus. The interspecies divergences in clade $\mathrm{D}$ are the lowest observed amongst the Lutjaninae species, with an average sequence divergence of $2.5 \%( \pm 1.4)$, ranging from $1.0 \%$ to $3.1 \%$. Clade E contains $L$. lemniscatus, L. lutjanus, L. vitta, L. madras, L. fulviflamma, L. ehrenbergii, L. carponotatus, and both types of $L$. russellii, with an average sequence divergence of $9.0 \%( \pm 0.6)$, ranging from $6.1 \%$ to $11.9 \%$. The maximum divergence in clade $\mathrm{E}$ is shared between both types of $L$. russellii with $L$. madras. A separate branching between the Indian and western Pacific types of $L$. russellii is supported by $4.2 \%$ pairwise sequence divergence. The western Atlantic L. cyanopterus and eastern Pacific $L$. novemfasciatus cluster unexpectedly in clade $\mathrm{F}$ together with the following western Pacific Lutjanus: L. rivulatus, L. stellatus, L. johnii, L. bohar (JF952787), L. quinquelineatus, L. notatus, $L$. kasmira, $L$. bengalensis, and $L$. argentimaculatus; the average sequence divergence is $12.4 \%( \pm 0.8)$. In clade $F$, the lowest sequence divergence is $2.9 \%$ between $L$. novemfasciatus and $L$. cyanopterus, whereas sequence divergences between the western Pacific Lutjanus range from 5.2\% to $16.4 \%$.

Apart from L. bohar (16.3\%), intraspecies divergences of the Lutjaninae range from $0.0 \%$ to $1.9 \%$, with an average of $0.3 \%( \pm 0.1)$. Without considering $L$. cyanopterus and $L$. novemfasciatus, the interspecies divergences of Lutjaninae between western Atlantic species (range: 1.0-12.7\%; average: $8.4 \% \pm 0.9$ ) are comparatively lower than those between the western Pacific species (range: 5.2-20.6\%; average: $14.1 \% \pm 0.3)$. de tasa incorporada para el modelo de sustitución en el análisis bayesiano: $[\mathrm{A}-\mathrm{C}]=1.0000$; $[\mathrm{A}-\mathrm{G}]=19.1232 ;[\mathrm{A}-\mathrm{T}]$ $=1.0000 ;[\mathrm{C}-\mathrm{G}]=1.0000 ;[\mathrm{C}-\mathrm{T}]=11.1862 ;[\mathrm{G}-\mathrm{T}]=1.0000$. También se observaron frecuencias desiguales de las bases en RC, de 0.3801, 0.2024, 0.1120 y 0.3056 para A, C, G y T, respectivamente. La matriz de tasa incorporada para $\mathrm{RC}$ fue $[\mathrm{A}-\mathrm{C}]=0.6564 ;[\mathrm{A}-\mathrm{G}]=3.9776 ;[\mathrm{A}-\mathrm{T}]=1.0000 ;[\mathrm{C}-\mathrm{G}]=$ $0.6564 ;[\mathrm{C}-\mathrm{T}]=3.9776 ;[\mathrm{G}-\mathrm{T}]=1.0000$.

\section{Árbol filogenético basado en las secuencias de COI}

El filograma de COI muestra que las subfamilias Etelinae, Apsilinae y Paradicichthyinae ocupan una posición basal respecto a Lutjaninae (fig. 1). Todas las especies de la subfamilia Lutjaninae forman un clado monofilético excepto L. bohar, ya que L. bohar (EF609394) no se agrupó con su conespecífico L. bohar (JF952787).

Las especies de la subfamilia Lutjaninae se agruparon en seis clados principales con base en una combinación de ramas bien sostenidas y definiciones previas de clados (Miller y Cribb 2007, Victor et al. 2009, Wang et al. 2010, Gold et al. 2011). Los clados A-E están sostenidos con probabilidades posteriores superiores a 0.90 , mientras que el clado F con sólo 0.73 . El orden de ramificación se resolvió para los clados A-C; sin embargo, los clados D-F forman una politomía. El clado A agrupa P. pinjalo, L. malabaricus, $L$. adetii y $L$. sebae, con una divergencia promedio de las secuencias de $12.9 \%( \pm 1.2)$; la menor divergencia fue $11.85 \%$ entre $L$. adetii y $L$. malabaricus, y la mayor fue $14.0 \%$ entre P. pinjalo y L. sebae. El clado B consiste de Macolor niger y dos especies de la familia Caesionidae (Pterocaesio diagramma y Caesio caerulaurea), con una divergencia promedio de las secuencias de $10.9 \%( \pm 0.4)$. Los clados C y D contienen las especies de Lutjanus del Atlántico occidental y el Pacífico oriental, mientras que las especies de Lutjanus en los clados E y F son principalmente del Pacífico occidental y el océano Índico. Ocyurus chrysurus se encuentra en el clado C junto con L. analis, L. buccanella, L. synagris, L. mahogoni, L. vivanus, L. purpureus y L. peru; la divergencia de las secuencias varía de $1.9 \%$ a $8.9 \%$, con una divergencia promedio de $6.3 \%( \pm 0.6)$. El clado D contiene sólo a L. griseus, L. jocu y L. apodus; la divergencia interespecífica de las secuencias varía de $1.0 \%$ a $3.1 \%$, con una divergencia promedio de $2.5 \%( \pm 1.4)$. El clado E contiene a L. lemniscatus, L. lutjanus, $L$. vitta, $L$. madras, $L$. fulviflamma, L. ehrenbergii, L. carponotatus y ambos tipos de $L$. russellii; la divergencia entre especies varía de $6.1 \%$ a $11.9 \%$, con una divergencia promedio de $9.0 \%( \pm 0.6)$. En el clado E, la mayor divergencia es compartida por ambos tipos de $L$. russellii con L. madras. Una ramificación entre L. russellii del océano Índico y el Pacífico occidental es apoyada por una divergencia de secuencias por pares de $4.2 \%$. En el clado F, L. cyanopterus del Atlántico occidental y L. novemfasciatus 


\section{CR-based phylogenetic tree}

The CR phylogram (fig. 2) indicates the monophyly and affinities of 12 Lutjaninae species, with three well supported clades corresponding to clades A, E, and F in the COI phylogeny (fig. 1). The tree affirms the clustering of $P$. pinjalo, $L$. malabaricus, and L. sebae as a clade (clade A). In clade E, the two types of $L$. russellii cluster with $L$. carponotatus, $L$. fulviflamma, L. lutjanus, L. madras, and L. vitta, whereas clade F contains L. argentimaculatus, L. quinquelineatus, and L. johnii.

The CR tree also shows the separation of the two types of L. russellii, with pairwise sequence divergence of $10.8 \%$. The intraspecies divergences of other species range from $0.5 \%$ to $6.7 \%$, with an average of $1.8 \%( \pm 0.8)$.

\section{Discussion}

The present COI phylogeny is congruent with phylogenies of Lutjanidae from other studies that used different mitochondrial and nuclear genes (Miller and Cribb 2007, Guo et al. 2007, Wang et al. 2010, Gold et al. 2011). Our clades A, C, D, and F of Lutjaninae correspond to clades A, C, D, and F of Gold et al. (2011), whereas our clades B and E correspond to species clusters in Miller and Cribb (2007). Additionally we propose the basal position of Paradicichthyinae to Lutjaninae, in addition to Apsilinae and Etelinae (Johnson 1980, Gold et al. 2011).

Despite having fewer taxa in the CR phylogeny, we found that affinities between species are congruent with those inferred by COI. Such congruence between CR and other mitochondrial genes may indicate a lower effect of homoplasy in CR, as previously reported (Bernatchez and Danzmann 1993, Zhu et al. 1994), and thus the usefulness of CR for testing phylogenetic relationships between closely related species of Lutjaninae.

Our phylogram also supports the close relationship between L. sebae, L. malabaricus, and L. adetii as inferred in previous studies (Guo et al. 2007, Miller and Cribb 2007, Wang et al. 2010, Gold et al. 2011), with the addition of $P$. pinjalo into this basal clade. In fact, $P$. pinjalo shares similar morphological characteristics with $L$. malabaricus and L. sebae: dorsal fin with XI spines and 13 to 14 soft rays, body depth 2.7 times in standard length, vomerine tooth patch crescentic without posterior extensions, smooth tongue, and total gill rakers ranging from 22 to 23. Based on the taxonomic keys of Lutjanidae (Anderson and Allen 2001), both Lutjanus and Pinjalo have 20 or less gill rakers on the lower limb of the first gill arch, but are separate genera based on the head profile, longitudinal scale row pattern, and the absence or presence of anterior fang-like canines. However, these distinguishing characters are not exclusive as some are shared by a few Lutjanus species. Head and trophic features are also usually subjected to convergent evolution (Gold et al. 2011) that confounds reliable taxonomic classification. Alternatively, colorations and body patterns show better correlation del Pacífico oriental se agrupan inesperadamente con las siguientes especies de Lutjanus del Pacífico occidental: $L$. rivulatus, L. stellatus, L. johnii, L. bohar (JF952787), L. quinquelineatus, L. notatus, L. kasmira, L. bengalensis y L. argentimaculatus. En el clado F, la divergencia promedio fue de $12.4 \%$ ( \pm 0.8$)$; la menor divergencia fue de $2.9 \%$ entre $L$. novemfasciatus y $L$. cyanopterus, mientras que la divergencia entre las especies de Lutjanus del Pacífico occidental varía de $5.2 \%$ a $16.4 \%$.

A excepción de L. bohar (16.3\%), la divergencia intraespecífica de la subfamilia Lutjaninae varía de $0.0 \%$ a $1.9 \%$, con un promedio de $0.3 \%( \pm 0.1)$. Sin considerar a $L$. cyanopterus y L. novemfasciatus, las divergencias entre las especies de Lutjaninae del Atlántico occidental (de 1.0\% a $12.7 \%$; promedio: $8.4 \% \pm 0.9$ ) son comparativamente menores que las divergencias entre las especies del Pacífico occidental (de 5.2\% a 20.6\%; promedio: $14.1 \% \pm 0.3$ ).

\section{Árbol filogenético basado en las secuencias de RC}

El filograma de RC (fig. 2) muestra la monofilia y las afinidades de 12 especies de la subfamilia Lutjaninae, con tres clados bien sostenidos que corresponden a los clados A, E y F en la filogenia de COI (fig. 1). El árbol confirma la agrupación de $P$. pinjalo, L. malabaricus y $L$. sebae en un clado (clado A). En el clado E, los dos tipos de $L$. russellii se agrupan con L. carponotatus, L. fulviflamma, L. lutjanus, L. madras y L. vitta, mientras que el clado $\mathrm{F}$ contiene a L. argentimaculatus, L. quinquelineatus y L. johnii.

El árbol de RC también muestra la separación de los dos tipos de L. russellii, con una divergencia de secuencias por pares de $10.8 \%$. La divergencia intraespecífica de otras especies varía de $0.5 \%$ a $6.7 \%$, con un promedio de $1.8 \%( \pm 0.8)$.

\section{DISCUSIÓN}

La filogenia inferida a partir de COI es congruente con las filogenias de la familia Lutjanidae obtenidas en otros estudios con diferentes genes mitocondriales y nucleares (Miller y Cribb 2007, Guo et al. 2007, Wang et al. 2010, Gold et al. 2011). Nuestros clados A, C, D y E de Lutjaninae corresponden a los clados A, C, D y F de Gold et al. (2011), mientras que nuestros clados $\mathrm{B}$ y E corresponden a las agrupaciones de especies de Miller y Cribb (2007). Proponemos que, además de las subfamilias Apsilinae y Etelinae (Johnson 1980, Gold et al. 2011), Paradicichthyinae ocupa una posición basal respecto a Lutjaninae.

A pesar de tener menos taxones en la filogenia inferida de la RC, las afinidades entre especies fueron congruentes con las inferidas a partir de COI. Esta congruencia entre la RC y otros genes mitocondriales podría indicar un menor efecto de la homoplasia en la primera, como ya ha sido documentado (Bernatchez y Danzmann 1993, Zhu et al. 1994), y por tanto, la utilidad de la RC para examinar la relación filogenética entre las especies de Lutjaninae estrechamente relacionadas. 


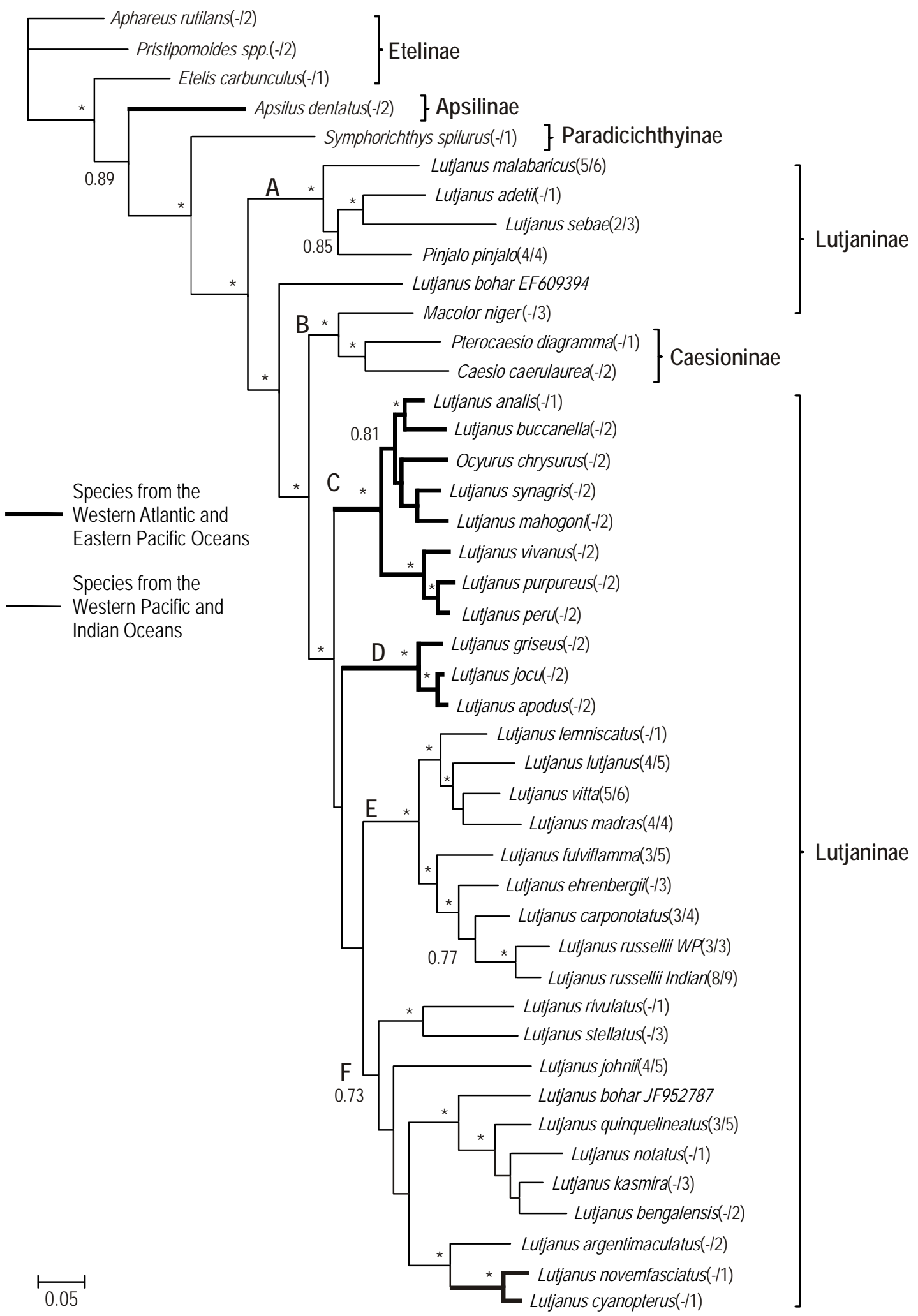

Figure 1. Bayesian phylogram of 43 species of Lutjanidae showing six clades (A-F), as inferred from cytochrome c oxidase subunit I. Posterior probabilities are shown at branch node, with asterisks indicating values higher than 0.90 . The number of sequence(s) generated in this study over the total sequence(s) used in the analysis is shown in parentheses after species name.

Figura 1. Filograma de 43 especies de la familia Lutjanidae con seis clados (A-F), inferido mediante análisis bayesiano del gen mitocondrial citocromo c oxidasa subunidad I. Las probabilidades posteriores se muestran en los nodos de ramificación; los asteriscos indican valores superiores a 0.90. Después del nombre de la especie se muestra entre paréntesis el número de secuencia(s) generadas en este estudio sobre el total de secuencia(s) usadas en el análisis. 
Chu et al.: Phylogenetic relationships of selected genera of Lutjanidae

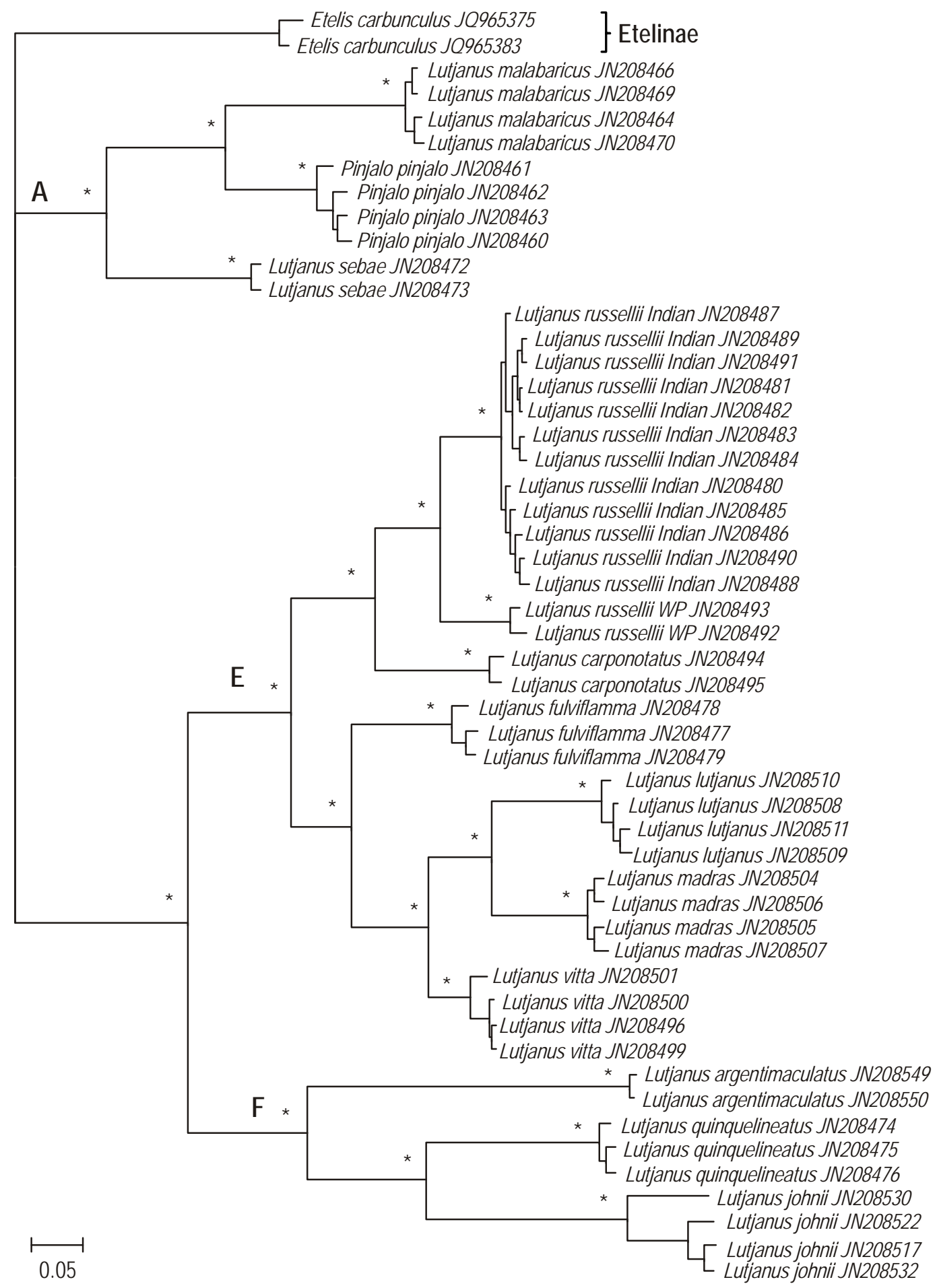

Figure 2. Bayesian phylogram of 12 species of Lutjaninae inferred from the control region. Clades A, E, and F correspond to the respective clades in figure 1 . The asteriks at the branch nodes indicate posterior probabilities higher than 0.90 .

Figura 2. Filograma de 12 especies de la subfamilia Lutjaninae, inferido mediante análisis bayesiano de la región control. Los clados A, E y F corresponden a los clados respectivos en la figura 1. Los asteriscos en los nodos de ramificación indican probabilidades posteriores superiores a 0.90 . 
to phylogenetic relationships (Shaw et al. 2000, Wang et al. 2010), as also observed between P. pinjalo, L. malabaricus, and L. sebae.

While the affinities among $L$. russellii, L. fulviflamma, $L$. carponotatus and $L$. vitta have been reported in Miller and Cribb (2007), we have further separated the two types of L. russellii. The $4.2 \%$ divergence in COI sequences between the two conspecifics of $L$. russellii supports the recognition for separate species (Avise 2000, Zhang and Hanner 2011). Our CR phylogeny also confirms such separation with expectedly higher divergences. Besides being geographically separated, the adults of the Indian type of $L$. russellii have body stripes, whereas the adults of the western Pacific type of L. russellii lack body stripes (Anderson and Allen 2001). Therefore, the Indian and western Pacific types of $L$. russellii should be recognized as two separate species based on the high level of divergences, geographical separation, and morphological dissimilarities.

The basal clades in our tree represent species distributed in the western Pacific, which is in accordance with the suggestion that western Atlantic species are derived from Indo-Pacific lineage (Miller and Cribb 2007, Gold et al. 2011). The relatively low interspecies divergence between the western Atlantic species of Lutjaninae also indicates their recent divergences as compared to other species from the western Pacific.

In summary, the phylogenetic tree inferred using COI and CR supports the monophyly of all the Lutjanus species analyzed except for the two "types" of $L$. bohar. We propose that $P$. pinjalo be subsumed into Lutjanus as molecular and morphological evidences have revealed the close affinity of P. pinjalo with the Lutjanus red snappers. Further research using both mitochondrial and nuclear genes to clarify whether the two types of $L$. russellii are different species is also warranted.

\section{ACKNOWLEDGMENTS}

This research was fully funded by the University of Malaya through UMRG and PPP research grants (RG032/ 09SUS and PS225/2009C, respectively). Our appreciation goes to all the fishermen and lab-mates that assisted in the sampling of specimens.

\section{REFERENCES}

Allen GR. 1985. FAO Species Catalogue. Vol. 6. Snappers of the World. An annotated and illustrated catalogue of Lutjanid species known to date. FAO Fisheries Synopsis 6 (125), 208 pp.

Anderson WD, Allen GR. 2001. Lutjanidae. In: Carpenter KE, Niem VH (eds.), FAO Species Identification Guide for Fishery Purposes. The Living Marine Resources of the Western Central Pacific. Vol. 5. Bony Fishes, Part 3 (Menidae to Pomacentridae). FAO, Rome, pp. 2840-2918.

Asgharian H, Sahafi HH, Ardalan AA, Shekarriz S, Elahi E. 2011. Cytochrome c oxidase subunit 1 barcode data of fish of the Nayband National Park in the Persian Gulf and analysis using
Nuestro filograma también apoya la relación cercana entre L. sebae, L. malabaricus y L. adetii inferida en estudios previos (Guo et al. 2007, Miller y Cribb 2007, Wang et al. 2010, Gold et al. 2011), con la inclusión de P. pinjalo en este clado basal. De hecho, P. pinjalo comparte características morfológicas similares con L. malabaricus y L. sebae: aleta dorsal con XI espinas y de 13 a 14 radios blandos, profundidad del cuerpo de 2.7 veces en la longitud estándar, parche de dientes vomerianos en forma de media luna sin una extensión posterior, lengua lisa, y total de branquiespinas de 22 a 23. Según las claves taxonómicas de la familia Lutjanidae (Anderson y Allen 2001), tanto Lutjanus como Pinjalo tienen 20 o menos branquiespinas en la rama inferior del primer arco branquial, pero son géneros independientes debido al perfil de la cabeza, patrón de las hileras longitudinales de escamas, y la ausencia o presencia de caninos acolmillados anteriores. No obstante, estos caracteres distintivos no son exclusivos ya que algunos son compartidos por varias especies de Lutjanus. Las características tróficas y de la cabeza también tienden a estar sujetas a evolución convergente (Gold et al. 2011), lo cual dificulta una clasificación taxonómica confiable. Alternativamente, los patrones corporales y de coloración muestran una mejor correlación con las relaciones filogenéticas (Shaw et al. 2000, Wang et al. 2010), como ha sido observado entre P. pinjalo, L. malabaricus y L. sebae.

Miller y Cribb (2007) documentaron las afinidades entre L. russellii, L. fulviflamma, L. carponotatus y L. vitta, pero en este estudio hemos separados los dos tipos de L. russellii. La divergencia de $4.2 \%$ en las secuencias de COI entre los dos conespecíficos de $L$. russellii apoya la sugerencia de que son dos especies distintas (Avise 2000, Zhang y Hanner 2011). Nuestra filogenia inferida de la RC también confirma dicha separación con divergencias mayores esperadas. Además de estar separados geográficamente, los adultos de L. russellii del océano Índico tienen rayas corporales, mientras que los adultos de $L$. russellii del Pacífico occidental no las tienen (Anderson y Allen 2001). Por lo tanto, los dos tipos de $L$. russellii deberían ser considerados dos especies distintas debido al alto grado de divergencia, la separación geográfica y las disimilitudes morfológicas.

Los clados basales en nuestro árbol representan las especies distribuidas en el Pacífico occidental, lo cual concuerda con la sugerencia de que las especies del Atlántico occidental se derivan del linaje Índico-Pacífico (Miller y Cribb 2007, Gold et al. 2011). La divergencia relativamente baja entre las especies de la subfamilia Lutjaninae del Atlántico occidental también indica sus divergencias recientes en comparación con las especies del Pacífico occidental.

En resumen, el árbol filogenético inferido con base en las secuencias de COI y RC apoya la monofilia de todas la especies de Lutjanus analizadas excepto para los dos “tipos” de $L$. bohar. Se propone que $P$. pinjalo sea incluido en el género Lutjanus ya que las evidencias moleculares y morfológicas muestran la afinidad cercana entre $P$. pinjalo y los pargos rojos de Lutjanus. Se requieren estudios adicionales con 
meta-data flag several cryptic species. Mol. Ecol. Resour. 11: 461-472. http://dx.doi.org/10.1111/j.1755-0998.2011.02989.x

Avise JC. 2000. Phylogeography: The History and Formation of Species. Harvard Univ. Press, Cambridge, MA, 447 pp.

Bernatchez L, Danzmann RG. 1993. Congruence in control-region sequence and restriction site variation in mitochondrial DNA of Brook Charr (Salvelinus fontinalis Mitchill). Mol. Biol. Evol. 10: 1002-1014.

Chong VC, Lee PKY, Lau CM. 2010. Diversity, extinction risk and conservation of Malaysian fishes. J. Fish. Biol. 76: 2009-2066. http://dx.doi.org/10.1111/j.1095-8649.2010.02685.x

Chow S, Walsh PJ. 1992. Biochemical and morphometric analyses for phylogenic relationships between seven snapper species (subfamily Lutjaninae) of the Western Atlantic. Bull. Mar. Sci. 50: 508-519.

Gold JR, Volker G, Renshaw MA. 2011. Phylogenetic relationships of tropical western Atlantic snappers in subfamily Lutjaninae (Lutjanidae: Perciformes) inferred from mitochondrial DNA sequences. Biol. J. Linn. Soc. 102: 915-929.

Guo Y, Wang Z, Liu C, Liu L, Liu Y. 2007. Phylogenetic relationships of South China Sea snappers (genus Lutjanus; family Lutjanidae) based on mitochondrial DNA sequences. Mar. Biotechnol. 9: 682-688. http://dx.doi.org/10.1007/s10126-007-9012-6

Huelsenbeck JP, Ronquist FR. 2001. MRBAYES: Bayesian inference of phylogenetic trees. Bioinformatics 17: 754-755.

Johnson GD. 1980. The limits and relationships of the Lutjanidae and associated families. Bull. Scripps Inst. Oceanogr. 24: 1-114.

Lakra WS, Verma MS, Goswami M, Lai KK, Mohindra V, Punia P, Gopalakrishnan A, Singh KV, Ward RD, Hebert P. 2011. DNA barcoding Indian marine fishes. Mol. Ecol. Resour. 11: 60-71. http://dx.doi.org/10.1111/j.1755-0998.2010.02894.x

Masuda H. 1984. Genus Lutjanus. In: Masuda H, Amaoka K, Araga C, Uyeno T, Yoshino T (eds.), The Fishes of the Japanese Archipelago. Tokyo Univ. Press, Tokyo, pp. 169-170.

Miller TL, Cribb TH. 2007. Phylogenetic relationships of some common Indo-Pacific snappers (Perciformes: Lutjanidae) based on mitochondrial DNA sequences, with comments on the taxonomic position of the Caesioninae. Mol. Phylogenet. Evol. 44: 450-460. http://dx.doi.org/10.1016/j.ympev.2006.10.029

Parker PG, Snow AA, Schug MD, Booton GC, Fuerst PA. 1998. What molecules can tell us about populations: Choosing and using a molecular marker. Ecology 79: 361-382.

Posada D. 2008. jModelTest: Phylogenetic model averaging. Mol. Biol. Evol. 25: 1253-1256. http://dx.doi.org/10.1093/molbev/msn083

Posada D, Crandall KA. 1998. Modeltest: Testing the model of DNA substitution. Bioinformatics 14: 817-818.

Salini JP, Ovenden JR, Street R, Pendrey R, Haryanti, Ngurah. 2006. Genetic population structure of red snappers (Lutjanus malabaricus Bloch \& Schneider 1801 and Lutjanus erythropterus Bloch 1790) in central and eastern Indonesia and northern Australia. J. Fish Biol. 68: 217-234. http://dx.doi.org/10.1111/j.1095-8649.2006.01060.x

Shaw PW, Turner GF, Rizman-Idid M, Robinson RL, Carvalho GR. 2000. Genetic population structure indicates sympatric speciation of Lake Malawi pelagic cichlids. Proc. R. Soc. Lond. (B) 267: 2273-2280.

http://dx.doi.org/10.1098/rspb.2000.1279 genes mitocondriales y nucleares para aclarar si los dos tipos de $L$. russellii son especies distintas.

\section{Agradecimientos}

Este trabajo fue financiado por la Universidad de Malaya (UMRG: RG032/09SUS; PPP: PS225/2009C). Agradecemos a todos los pescadores y asistentes de laboratorio su ayuda en el muestreo de los especímenes.

Traducido al español por Christine Harris.

Steinke D, Zemlak TS, Hebert PDN. 2009. Barcoding Nemo: DNAbased identifications for the ornamental fish trade. PLoS ONE 4: e6300.

http://dx.doi.org/10.1371/journal.pone.0006300

Taggart JB, Hynes RA, Prodöhl PA, Ferguson A. 1992. A simplified protocol for routine total DNA isolation from salmonid fishes. J. Fish Biol. 40: 963-965. http://dx.doi.org/10.1111/j.1095-8649.1992.tb02641.x

Tamura K, Dudley J, Nei M, Kumar S. 2007. MEGA4: Molecular Evolutionary Genetics Analysis (MEGA) software version 4.0. Mol. Biol. Evol. 24: 1596-1599.

Victor BC, Hanner R, Shivji M, Hyde J, Caldow C. 2009. Identification of the larvae and juvenile stages of the Cubera snapper, Lutjanus cyanopterus, using DNA barcoding. Zootaxa 2215: 24-36.

Wang ZD, Guo YS, Tan W, Li L, Tang EP, Liu CW, Liu Y. 2010. DNA barcoding, phylogenetic relationships and speciation of snappers (genus Lutjanus). China Life Science 53: 1025-1030. http://dx.doi.org/10.1007/s11427-010-4034-0

Ward RD, Holmes BH. 2007. An analysis of nucleotide and amino acid variability in the barcode region of cytochrome c oxidase I (cox1) in fishes. Mol. Ecol. Notes 7: 899-907. http://dx.doi.org/10.1111/j.1471-8286.2007.01886.x

Ward RD, Zemlak TS, Innes BH, Last PR, Hebert PDN. 2005. DNA barcoding Australia's fish species. Philos. Trans. R. Soc. Lond. (B) 360: 1847-1857. http://dx.doi.org/10.1098/rstb.2005.1716

Zhang JB, Hanner R. 2011. DNA barcoding is a useful tool for identification of marine fishes from Japan. Biochem. Syst. Ecol. 39: $31-42$. http://dx.doi.org/10.1016/j.bse.2010.12.017

Zhang J, Huang H, Cai Z, Huang L. 2006. Species identification in salted products of red snappers by semi-nested PCR-RFLP based on the mitochondrial 12S rRNA gene sequence. Food Control 17: 557-563.

http://dx.doi.org/10.1016/j.foodcont.2005.01.011

Zhu D, Jamieson BGM, Hugall A, Moritz C. 1994. Sequence evolution and phylogenetic signal in control-region and cytochrome b sequences of rainbow fishes (Melanotaeniidae). Mol. Biol. Evol. 11: 672-683.

Received March 2013, received in revised form July 2013, accepted October 2013. 